CARNETS OE Carnets de géographes

GÉOGRAPHES.

$1 \mid 2010$

Varia

\title{
The researcher as the ball in a political game
}

Claire Benit-Gbaffou

\section{(2) OpenEdition}

Journals

Electronic version

URL: http://journals.openedition.org/cdg/1897

DOI: $10.4000 /$ cdg. 1897

ISSN: 2107-7266

Publisher

UMR 245 - CESSMA

Electronic reference

Claire Benit-Gbaffou, «The researcher as the ball in a political game », Carnets de géographes [Online], 1 | 2010, Online since 01 October 2010, connection on 07 May 2019. URL : http:// journals.openedition.org/cdg/1897; DOI : 10.4000/cdg.1897

\section{@(@) $\Theta \Theta$}

La revue Carnets de géographes est mise à disposition selon les termes de la Licence Creative Commons Attribution - Pas d'Utilisation Commerciale - Pas de Modification 4.0 International. 


\section{The researcher as the ball in a political game}

\section{Claire Benit-Gbaffou}

Maître de conférences à l'Ecole d'Architecture et d'Urbanisme de l'Université de Wits à Johannesburg; chercheur associée au laboratoire Gecko (Paris Ouest Nanterre La Défense); coordonne, avec le Professeur Alan Mabin (université de Wits), un programme CORUS sur «La voix des pauvres dans la gouvernance urbaine : mobilisation, participation et politique dans les grandes villes sud-africaines »

A former version of this text was presented to the CORUS seminar : 'The voice of the poor in uban governance - participation, mobilization and politics in South African cities', Cape Town, 23-25 November 2009

Elements of context - This research, undertaken by PLANACT (an NGO) and for which I am playing a role as research adviser, is about the place of residents' participation in a hostel renovation project ${ }^{\mathrm{i}}$. The hostel ${ }^{\mathrm{ii}}$ is located on former mining ground, close to the metropolitan fresh products market. It is not far from the city center in absolute terms (about 10 kilometers) and well connected to it through taxi routes: but in a no man's land made up of industrial zones, mine dumps, and toxic waste. It is also a political enclave - an ANC stronghold in a $\mathrm{DA}^{\mathrm{iii}}$ ward, which mostly comprises (besides the hostel) former white working class suburbs.

The hostel renovation is conducted by Joshco (Johannesburg Social Housing Company, an entity that is funded by the municipality and is accountable to it but has its own management structure), who also manages the rental units. The project is about converting a former male hostel (predominantly occupied by Xhosa residents, from the Eastern Cape) into family units, inviting the wife and children to join their long-gone husband. It is perceived by most residents as a radical change that has its own challenges (in particular when the migrant husband has established a relationship with another women; but even more generally because the coming of women challenges the former masculine environment and requires some reshuffling of traditional gender roles).

In the process of conversion and renovation of the hostel, Joshco has been mainly interacting with the old Tenants Committee, composed of four men and often criticized by other stakeholders (including Joshco itself), for not being representative of all residents. Two other local organizations are powerful locally: the ANC and SANCO structures (partners in what is called the 'Alliance Forum') '. They are said to have a wider audience, and are extremely critical of (and sometimes violently oppositional to) Joshco's project. It took a long time for us to identify who the leaders were and to organize a meeting, all the more that we were introduced in the hostel by Joshco's caretaker, who was reluctant to put us in touch with people he perceived as 'trouble makers', and was also very wary that the research process could open conflict and even violence in City Deep Hostel, especially in electoral times ${ }^{\mathrm{v}}$. I 
had subsequently issued a poster and flyers in English and Xhosa to tell residents about the research and inform them that its purpose was to talk with all stakeholders and hear all voices, from an outsider's, independent perspective. After several months of fieldwork in the area, and eventually individual interviews with the local ANC representative, and the SANCO chair, I asked the former if I could attend an Alliance Forum executive committee meeting ${ }^{\text {vi }}$ (since there was no public meeting in the pipeline) and he invited me.

\section{Fieldwork notes City Deep Hostel- 12.06.09 ${ }^{\text {vii }}$ Alliance Forum executive committee meeting, 10.06.09, City Deep Hostel, boardroom, $18 \mathrm{~h} 00$.}

During the whole meeting I am the ball in a ping-pong game, whose players I can only partly identify: in turn, the political battle is between SANCO and the ANC (the two members of the Alliance); between the Alliance and Joshco (not represented at the meeting); and between the Alliance and the Mayor (not represented at the meeting). My overall first impression is of the extreme political skills displayed by the main players, who direct the discussion at leisure, and push me where they want to push me (not a very agreeable, but instructive, position for me). Secondly, they clearly are playing and enjoying the game (at my expense), although some degree of pity (especially since I am seven months pregnant) shows up at the end. But they are clearly interested in the research results as they see its potential political implications, and not willing to close the door - this has been a game and a rite of passage. Thirdly, it is not an homogeneous group, with SANCO and ANC chairs being clearly pushed by power dynamics and enjoying the game; ANC voting district chair and Alliance chair (chairing the meeting) mostly remaining silent but trying to bring things forward and find pragmatic solutions, supporting me although in a very light and subtle way.

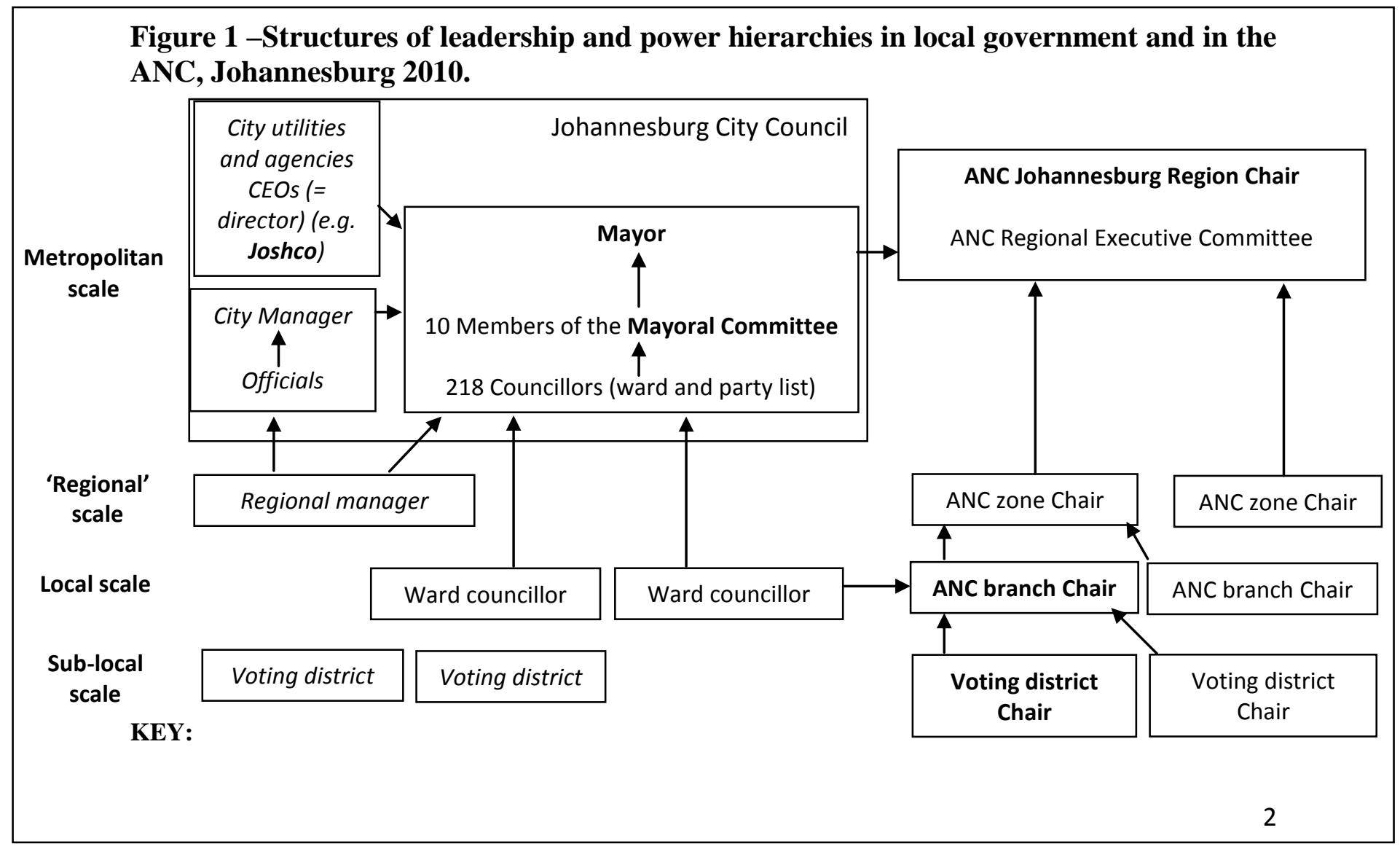


In italics - administrative positions or structures.

In bold, leaders or structures mentioned in the text.

Arrow meaning: 'reports to, is accountable towards' (so the direction of the arrow is indicating power)

NB: Not all ANC branches have voting district chairs. It is the case in our study because the hostel is an ANC stronghold in a broader DA ward - the ANC branch chair not being a hostel resident, it was important to have an $\mathrm{ANC}$ representative in the hostel (hence the voting district chair).

NB2: This structure is made more complex by the fact that these various positions (in local government and in the ANC) are sometimes held by the same persons. For instance, Amos Masondo, the Mayor or Johannesburg, is also the ANC regional Chairperson. But he is weakened in the ANC regional structure by a strong opposition in the regional executive committee.

\section{Figure 2. Structure of the Alliance executive meeting attended}

\begin{tabular}{||c||c|}
\hline \multicolumn{2}{|c|}{ Alliance Forum - executive committee } \\
\hline ANC \\
\hline ANC Chair - Neil \\
\hline SANC voting district Chair - William \\
\hline \begin{tabular}{c|c|} 
ANC branch secretary - \\
Sinethemba (chairing the meeting)
\end{tabular} \\
\hline \begin{tabular}{c} 
SANCO Chair - John \\
\hline \\
\hline
\end{tabular} \\
\hline
\end{tabular}

I am attending the meeting with Lerato, one of my Planning students that I have asked to join to help me with translation issues, as my research partner from PLANACT, Malachia, could not be present. We are waiting for members to join the meeting: SANCO Chair John and Alliance Forum Chair Sinethemba ${ }^{\text {viii }}$ (they are crucial to the point and without them coming, other speak of cancelling the meeting). In the meantime, informal discussion occurs mainly between the ANC branch Chair (Neil) and the ANC voting district chair (William whom I interviewed previously and who invited me to the meeting). They complain (in Zulu) about the Mayor, Amos Masondo, who does not care about their requests for meetings, and (halfjokingly) discuss of just organizing a toyi-toyi ${ }^{\mathrm{ix}}$ and hand him over a memorandum. They joke about Strike (Ralegkoma, the Member of the Mayoral Committee (MMC) for Housing in Council $^{\mathrm{x}}$ ), the fact that he is double-faced, when is he going to walk to $\mathrm{COPE}^{\mathrm{xi}}$, no, he probably won't...

\section{First battle - SANCO and ANC}

Enters SANCO chair (John), his secretary Celia (that Malachia, my fellow researcher from PLANACT, and I have met and interviewed a few days ago), as well as Alliance Forum Chair, Sinethemba, who is about to start the meeting when he is interrupted by SANCO Chair. John, who is a 'strong man' with a deep voice and large shoulders, objects to our presence here, saying he is very surprised to see us here, since he has not been consulted about it as a member of the Alliance Forum executive committee ('exco'). Moreover, he states that he has met with me in the past days, that I have requested to attend the exco meeting and he has told us he would get back to us, which he has not done yet. He therefore suggested the meeting to be cancelled. Doing otherwise would be like 'pointing a gun at his head'.

ANC Chair, Neil, offers a counter proposition: that the Forum allows us to present why we are here and the research project, and then that we leave the meeting. He is seconded by John's right hand, Celia, who I think sympathize with my (pregnant) condition.

I also make a contribution, clarifying the fact that I approached William to be granted permission to attend this meeting; that I indeed met with John and requested permission from 
him, but to attend a SANCO exco meeting, which I thought was different. There is therefore no intention from my side to 'point a gun at anyone's head'. At that stage, John reacts: 'no, it is not you I was talking about', and I realize this is not about me. However, Sinethemba uses my statement to try and propose a way forward, as I 'clearly could not know that SANCO and the Alliance work so closely together' and we should find a way forward to solve the issue now. It helps, to play the stupid little white girl...

After a heated discussion, Sinethemba chairing the meeting makes a decision: since Neil's proposal has been seconded, let us allow Dr Claire to present, ask her questions and then let her go. The agenda is adopted finally.

\section{Second round - battle between the Alliance and Joshco}

The ANC chair (Neil) is however not an ally or support for me: he has a very specific agenda when allowing me to present the project. After I have traced the contours of PLANACT (a non profit, non political, non-governmental organization), of the project (voices of community into the renovation of the hostel), of the process (I state that I will be interviewing each stakeholder to try and understand each viewpoint; that I am happy to check with interviewees if they are satisfied with the way we have captured their viewpoint; that I am willing to present the draft report for comments), Neil starts to throw questions at me that at first are very unclear.

He asks about who 'instructed' us, who 'mandated' us to do this research; and what is our objective. I try to further explain that nobody instructed or mandated us; to explain the nature of PLANACT activities (using their motto, 'making cities work for people'). He says I am sidelining the question and repeats it again and again, more and more aggressively, till SANCO's Chair comes to my rescue by going more directly to the point - How did you get here? Who told you about City Deep?

I then make a blunder, naively (well, also very much under pressure...) saying that we selected several case studies including City Deep because the City of Johannesburg indicated it as a 'successful project' (and also, but they don't hear me because obviously this is not relevant to them, that we wanted to do this research in a hostel environment because we assumed residents would be strongly organized). Immediately interest jumps, WHO in the city? Fortunately I am able to state that it is not the Department of Housing (with which they are at present in conflict - I am quite aware of that!), but the Department of Corporate Governance - but I become more aware that every word from this project is weighed and can be used as a political weapon in other battles.

And it is not over: the next question is then: how did you get in the hostel, who was your contact - they obviously knew it was Joshco ${ }^{\text {xii }}$. When I formulated this, both ANC and SANCO chairs played outrage, 'Joshco is not running this area', 'WE are running this area', 'how could they give you permission to enter this area without consulting us?', 'this is a blatant disrespect for our structures'. At that point I was more distant, both quite ironic and interested. This is a DA ward; ANC chair had asked me previously: "why do you want to study community participation? You should be aware of our legislation on local government that plans for participation ${ }^{\text {xiii }}$ - I had replied we needed to see it work in practice, from the ground, at a project level. Now, conveniently, the ward system's legitimacy is forgotten and it is 'us' (the ANC/ the Alliance) who run this area. ANC chair suggests that we 'burn all the material we gathered' and 'start afresh, following the correct protocol'.

I argue that I understand their position, that I am aware of a communication problem with Joshco, but that it seems rather unfair to ask me to solve such a problem, as I am an outsider and obviously do not have the capacity to do so.

All of a sudden, they shift - 'no no, it is not about Joshco, it is about consulting our political hierarchy'. And it is unclear during the rest of the conversation what they are talking about - 
the right to attend their (executive committee) meeting? Or the right to enter the hostel playing on the image of the 'no-go' area they have gained especially in the 1990s during political violence crystallized around hostels ${ }^{\text {xiv }}$ ? Is it my own perception, my own fears, or is violence really and effectively a usual way of solving conflict in the hostel ${ }^{\mathrm{xv}}$ ? Are they aware of these fears and playing on it? I tend to think they are.

\section{Third round - Battle between the Alliance and the Mayor}

The ANC chair suggests we approach the zonal and the regional chairpersons of the ANC (and the Regional Chair of SANCO) to ask for permission to conduct a research in City Deep Hostel (at a point he also mentions the Provincial Chair, and I bite my tongue not to ask, if he could also give me President Zuma's - the National Chair- phone number?).

He gives me a lecture about the 'practices of the apartheid time' (reference to apartheid is constant in the hostel environment, and extremely ambiguous, although not this time ${ }^{\mathrm{xvi}}$ ), where 'white people' used to come uninvited, ask questions, do their report which would not reflect the people's views but what people thought they were expecting. Coming to City Deep Hostel without following the right protocol, he argues, is doing like them. 'We all need to learn democracy, and this forum is a good place to start'. Sinethemba jokingly adds (to lighten the atmosphere, which is not tense but the accusation of apartheid practice is never light, no matter how instrumental it is), that one does not need to pay the R 15.000 fee to go to Wits University (where I teach), we have free lessons here (and I follow his path, saying, 'shh, shh, in front of my student! You want to deprive me of my job?' and everybody laughs). SANCO Chair reiterates ANC Chair comment and says we should ask permission from his Regional Chair. ANC Voting District Chair (who has been giving me looks of sympathy and light smiles throughout the meeting, but without saying much) says, in order to be pragmatic, that I should be given the contact numbers of the relevant people.

I then realize that it is, for sure, about teaching me a lesson (maybe because of my title, Dr. in an interview I heard that some hostel dwellers were deeply resentful about 'educated people who think they are better than us', although I don't think I have been boasting too much about this -stressing rather my difficulties with Zulu...). But it was also about making us contact the Mayor (which is also the ANC Regional Chair) about City Deep Hostel, as a way to point out that there are issues there and that they are under academic, if not political, scrutiny.

At that stage, I remain very quiet. Partly out of the fear of making other blunders (knowing everything I would say would be toyed with; even humor might trigger wrath, sincere or affected).

Sinethemba thanks us for our presence, our presentation and replies to questions, and apologizes for the way in which it has been received. The ANC Chair says that he hopes I understand there is nothing personal here; and that I should not go out in my state (i.e. pregnant) that late at night. SANCO Chair adds, 'Claire, don't stress too much about this, hey?'. Which I understand as them saying, 'OK, we have had a nice game, we've had fun, but this was a game'; or, maybe, 'you past the test, don't worry, it will go forward'.

Indeed, intertwined in this series of battles, another member (unidentified: came late, entered with John and sat next to him: SANCO executive committee member?) raises the issue of the findings of the research. Was it finished, could they get a presentation of our findings, before the final report was written, etc.? I replied that obviously it was not finished and although we had gathered some information already, it remained superficial and that was precisely the reason why we wanted to attend their meetings. But of course, it was part of the process I had presented, we would be very happy to let them check our quotations from them (for them to complement or correct), and to present them a draft version of the report. There were 
questions about the time frame, and I replied cautiously that obviously PLANACT had its own time constraints for the research; that I had my own (natural) time constraints (maternity leave from early July), and that we were hoping, if possible, to have done the bulk of the interviews by the end of the month; that we would then write the report and probably be able to present it end September/ October. Sinethemba immediately supported me, saying that I had very gently made a request and that the research could continue since there was limited time left.

This unidentified member stressed the fact he liked that I had committed to present the report to the Alliance- and people started referring to it as a 'White Paper' ${ }^{\text {xvii }}$ (saying that, like a White paper, you cannot write recommendations without consulting the people). The length of that discussion, as well as this nickname, made me understand better that everyone expected to be able to use the report politically, in their battles with Joshco and with the City, given the fact it was likely that it would be critical of the participatory process. It both reassured me (about the fact they wanted this research to go forward), and frightened me (about the difficulty we would have to keep the report balanced; about its future political manipulation in completely unknown directions - not necessarily to empower residents and ease communication with local authorities; but also in more complex and possibly petty political conflicts). This however is a challenge for the next step of the research...

\section{Post meeting personal reaction}

I left the meeting deeply puzzled and annoyed, very frustrated, slightly humiliated (even more after their final words of sympathy which I took first mainly as an expression of pity and some degree of machismo). It is not pleasant to be 'the ball' in a game, one feels powerless and even more: dispossessed of one's individuality, ability to talk, as each word you utter can be, and will be, turned against you. Not knowing for instance when humor is welcome to defuse situation; not certain of what you should or should not compromise on. For instance it was evident that requiring me to ask for 'permission' from the ANC to enter City Deep Hostel was illegitimate (and even if I had a permission to ask to 'enter an area', it is a DA ward after all; ANC does not have a mandate in this area) and a way for the ANC to try and build its legitimacy. I was tempted to refer to the apartheid dompass ${ }^{\text {xviii }}$, especially when accused of reproducing apartheid practices (but I am glad I refrained from it!). In fact it was never clear if permission was requested in order to enter City Deep Hostel, or to attend the Alliance Exco meetings - have the Alliance's endorsement of the process- which was more understandable. What helped of course was my relative understanding of the process and the political stakes, after months of fieldwork. I understood for instance the role the ANC sees itself playing in local societies, as the main platform for people's concerns and the legitimate local leader and authority (as opposed to local government structures ${ }^{\mathrm{xix}}$ ). Crafting a letter to the ANC Chair and SANCO Chair, requesting their help in the task they had given me (in fact asking them to contact their own hierarchy), was a necessary step if one wants to avoid indefinite delays (I doubt the Mayor would respond a demand from PLANACT), and gave me back some sense of agency.

As I reflect later, more broadly, on these processes, I realize how political sense is a skill and how I lack such a skill: conducting a meeting, creating tension and playing anger and later on, defusing it and slowing the pace, in alternating tension and relaxation necessary to keep the 'victim' pressurized but also confident enough to continue talking (and making blunders); framing questions in indirect ways that hides their real purpose; identifying possible political weapons and looking deep for evidence; etc. It is like playing chess and constantly anticipating the other's movement, to bring him (her) where you want to bring him 
(her). What was puzzling to me was the fact that in spite of my relative understanding of the local political conflicts and stakes, even of individual positions of participants (and my intuitions about their rivalries and contrasted personalities and political styles), I was unable to counteract the political play I was engaged in, to foresee where each participant was aiming at and to be a player instead of being 'the ball'. Of course, I was coming into a game that the participants had spent years, if not decades, playing together... My academic understanding gave me the power to realize what was going on, but my only way of preventing it to go further was eventually to remain as silent as possible (a challenge when you are grilled and questioned, or when you are asking for a favor - here, attending the meeting). There, were displayed different types of knowledge, or rather different ways of using knowledge as an instrument of power (and of course academic knowledge is also power, as the last part of the discussion - about the findings and the 'White Paper'- expresses clearly).

Would it even have been possible for me to 'know better'? One always tends to blame oneself for lack of foresight or for one's blunders. On the other hand, obviously any new player in a game that has taken years, if not decades, to build and establish, is at a disadvantage - no research process (at least that has not been built over several years as well) can replace this time and depth of inter-connectedness - so maybe the best response is just to observe and learn. But beyond this time / depth gap, I definitely had a strong sense that there was something generic, not locally-specific, in this game. In particular I had had exactly the same impression (being a ball in political game) when I interacted, this time as an activist, with local leaders in Alexandra township - also an 'enclave', a dense, free-hold black township in the middle of Sandton (formerly white privileged suburb) where innumerable politicians and activists (many of which are now in prominent political positions nationally) have undergone their political education. This was a similar kind of 'closed circle', where a high degree of political maneuvering and astuteness might be the only resource attainable to local residents, used both against outsiders (apartheid state agents) and insiders (rival leaders).

Obviously I am not entirely naïve and have learnt to play with different belongings, registers, languages. Here, the ability to speak a little bit of Zulu (however limited) is important, if not to 'break' barriers, at least to unsettle too easy categories, and therefore bring conversation towards a less formal arena. Sometimes, it makes sense to play with these categories ('the stupid little white girl') at least implicitly - although the play around the vocabulary of apartheid is always heavy and one never is sure of what it will unleash; all players are generally aware it is a 'card' in the game, but in multi-racial settings it is almost impossible to counter it (impossible to say: 'no, I am not a racist!'). Is it therefore only a matter of insufficient communication skills - and here my insufficient ability to hide information or to disclose it as minimally as possible? Is there such a thing as 'communication skills'? Even if it is a field of expertise as such, I tend to understand it rather as quite specific to this form of interaction (quite different, for instance, from communication skills required to teach, or to market a product, etc.). Aren't actually these skills (communication and power games in a political setting) actually one of the objects of this research?

This experience also makes me reflect on the problematic relationships between 'low' (or petty) politics and 'high' politics. I was, in the initial formulation of the research question, and to some extent still am, looking for 'high' politics - how the Alliance is able (or not) to claim a voice in the renovation and hostel management process in the name of residents. And it is, to some extent: its action has led to a decrease in electricity tariffs charged to residents; to the suspension of the eviction of the wife of a legal tenant, after he passed away; etc. ${ }^{x}$ 'Low' politics, these never-ending power games even inside the Alliance, are often perceived 
as detrimental to 'high' politics. They are generally theorized as disconnected from it - I have at least not encountered yet theoretical frameworks that attempt to capture both in their complex articulations ${ }^{\mathrm{xxi}}$. In City Deep Hostel (and elsewhere) it also has been the case: many initiatives taken by some Alliance members, that would have improved the residents' lives, were blocked by others out of political rivalry. But it is not enough to see low politics as opposed and detrimental to high politics. First the two are intrinsically connected - where there is a potential to change things, when there is agency and power (whatever it is), there is competition for it, competition for leadership and recognition. It is difficult to measure how important the potential for change or for access to resources needs to be to trigger power competition: it depends so much of local and personal contexts - for instance the existence or not of other platforms, for individuals or groups, of achievement and sense of self-importance. Secondly, could it be that this very intense political education - leading to these quite specific skills- is necessary to accomplish political victories at other levels of political engagement? I am not sure yet. What I am sure of is the necessity for better understanding party politics and power dynamics at a quite micro-level if I want to understand anything about the way in which residents, in their maybe limited ways, can bring about some change in their living environments.

\section{References}

AUYERO J, 2000. Poor people's politics: peronist survival networks and the legacy of Evita. Duke University Press.

BENIT-GBAFFOU C., forthcoming, "Party politics, civil society and local democracy - Reflections from Johannesburg", Geoforum, special issue on 'Political parties, the Poor and the City, reflections from South African cases', 2010.

BENIT-GBAFFOU C., MATHOHO M, 2010, "A Case Study of Participation in the City Deep Hostel Redevelopment", in PLANACT, Participation from the perspective of the Poor. Johannesburg. Available on www.planact.org.za.

BENJAMIN S., 2004. Urban land transformation for pro-poor economies. Geoforum 35, 177-187.

BLUNDO G., OLIVIER DE SARDAN P., 2001. La corruption quotidienne en Afrique de l'ouest. Politique Africaine 83, 8-37.

CHATTERJEe P., 2004. The Politics of the Governed: Popular Politics in Most of the World. New York: Columbia University Press.

CHIPKIN I, 2004, Nationalism As Such: Violence during South Africa's Political Transition, Public Culture, 16(2): 315-335.

ELDER G, 2003, "Malevolent Traditions: Hostel Violence and the Procreational Geography of Apartheid", Journal of Southern African Studies, 29(4), 921-935.

MINNAAR A (ed.), 1993, Communities in Isolation: Perspectives on Hostels in South Africa. Pretoria,South Africa: Human Sciences Research Council.

PIRIE G, DA SILVA M, 1986, "Hostels for African migrants in Greater Johannesburg", Geojournal, 12.2, pp. 173-182.

RAMPHELE M, 1993, A Bed Called Home: Life in the Migrant Labour Hostels of Cape Town. Edinburgh and Cape Yown: Edinburgh University Press and David Philip.

SEGAL L, 1991, "Hostel dwellers speak: the Human Face of Violence", Journal of Southern African Studies, 18(1), pp. 190-231.

SIMONE A., 2006. Reaching Larger Worlds: Negotiating the Complexities of Social Connectedness in Douala. Politique Africaine 100, 38-53.

SITAS A, 1996, "The New Tribalism: Hostels and Violence", Journal of Southern African Studies, Vol. 22, No. 2, pp. 235-248

ZUERN E, 2001. "South Africa's Civics in Transition: Agents of Change or Structures of Constraint?" Politikon: South African Journal of Political Studies, vol. 28, no. 1. 
${ }^{\mathrm{i}}$ The full research report and the chapter on City Deep Hostel (Bénit-Gbaffou and Mathoho 2010) are available on PLANACT's website, http://www.planact.org.za.

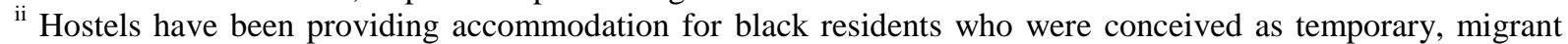
workers in pre 1994 South African cities (Pirie and Da Silva 1986). Some of them were managed by private companies (especially mining companies); some by municipalities. Traditional chiefs were often hired as hostel managers, in a form of indirect rule that efficiently kept internal social control (Minaar 1993). Single-sex hostels (male hostels mostly, sometimes female), they were meant to prevent full urbanization of black migrants who were in a way permanently temporary, and whose roots in their 'homeland' was maintained through the division of their family and their relative physical isolation from urban black townships (Ramphele 1993). Hostels crystallized fears and violence in urban areas in the 1990s, around complex ethno-political divisions opposing hostel dwellers to township residents, and instrumentalised by the apartheid regime (Chipkin 2004, Elder 2003, Segal 1991, Sitas 1996).

iii The Democratic Alliance (DA) is the main opposition party in South Africa.

iv The African National Congress (ANC) has got several hierarchised structures: local (through a branch that corresponds to the electoral ward; branch that is here divided into several voting districts); zonal (an aggregation of several branches often corresponding to a functional area, for instance a township: from 5 to 9 branches generally); regional (corresponding here to Johannesburg metropolitan boundary), provincial and national (see Figure 1). South African National Civic Organisations (SANCO) is a national federation of civics (residents associations that emerged mostly in black townships in the 1980s to fight apartheid), which has a similar structure but much less wide spread and functional with a much larger diversity of civics which do not necessarily follow national directives. SANCO has entered into a political alliance with the ANC at the national level, giving up what used to be its 'watchdog role' towards government because it was (arguably wrongly) considered useless in democratic, post apartheid times (Zuern 2001).

${ }^{v}$ The research started early 2009, and national elections were held in April 2009. We had to wait till after the elections to meet some of the leaders, to respect Joshco's request of not stirring an already unstable situation (in the meantime we carried on our interviews with other organizations and tenants). Even so, the SANCO contact given by Joshco was not the Chair but a SANCO disgruntled member - who had left SANCO leadership and was more sympathetic to Joshco's view. While we were greeting him (as the SANCO Chair we thought he was) in front of the hostel gate, the 'real' chair of SANCO happened to pass by and he enquired about our presence. He was outraged of being by-passed, disrupted the meeting, and requested us to 'follow proper procedure' by phoning him the following week to make an appointment with the 'right SANCO representative' (himself).

${ }^{v i}$ An executive committee meeting is not a 'public' meeting, as it is meant for leadership (executive committee members) and is supposed to deal with strategic issues.

${ }^{\text {vii }}$ These notes were written in English shortly after the meeting. They were slightly edited for publication, and complemented by footnotes and figures for clarity to the reader.

viii All the participants' names have been changed to protect anonymity.

${ }^{\text {ix }}$ Protest march, generally involving songs and dances popularized during the apartheid struggles.

${ }^{\mathrm{x}}$ In Johannesburg strong mayoral system, the Mayor appoints ten members of the Mayoral Committee (MMC) amongst the elected councilors (he does so in his political majority, the ANC, and not according to political parties' shares within the Council). Each MMC has a portfolio which corresponds to an administrative department in the City (Housing, Infrastructure, Health, Sports and Recreation, etc.).

${ }^{x i}$ COPE, Congress of the People, is a new political party that was constituted in 2008 as a splinter group from the ANC, after the Polokwane Conference (December 2007) which consecrated one ANC faction (Zuma's faction, the current South African president) over the other (Thabo Mbeki's faction - the former president). It is often seen by ANC politicians as a major threat to the party as it taps into similar anti-apartheid struggle credentials and could gather all those who are disappointed by the ANC.

xii See note iv.

xiii This legislation makes the ward councilor and around him/her, the ward committee, the key element of community participation.

${ }^{\text {xiv }}$ See note ii.

${ }^{x v}$ See note iv. After being interrupted by SANCO chair, the former SANCO leader that Joshco had put us in touch with indicated that he was willing to grant us an interview, but not here, not then. He nevertheless immediately invited us to his place but did not utter a word as there was a visitor. We subsequently organized a meeting in PLANACT office rather than in the hostel, as we did with several interviewees. These fears, the fact that violence is also a 'normal' way of settling conflicts, were later confirmed by episodes (see PLANACT report 2010 for more details). 
${ }^{\mathrm{xvi}}$ Apartheid is obviously loathed and condemned by all, but there is also an expression of nostalgia for the 'old times' where men were respected, when order was prevailing, etc. Significant is the debate with Joshco about how the renovated hostel should work - residents request all public facilities be provided on site (postal services, clinic, school, etc.), whereas Joshco wants to break away from the apartheid legacy of the 'enclave' and encourages residents to use services from surrounding suburbs.

xvii Official policy documents.

xviii The dompass was the permit that each Black urban resident was supposed to permanently carry with him in order to justify his/her presence in urban areas (as Blacks were supposed to be temporary sojourners in cities, and authorization to live in the city often linked to their employment).

${ }^{\text {xix }}$ See Benit-Gbaffou, forthcoming.

${ }^{x x}$ For more detailed analyses see Benit-Gbaffou and Mathoho 2010.

${ }^{x x i}$ There are many texts analyzing how 'high' politics or specific development policies create a whole range of brokers, mediators, whose actions could be linked to 'low' or petty politics (Blundo and Olivier de Sardan 2001; Auyero 2000; Benjamin 2004; Simone 2006; Chatterjee 2004). But the focus is centered on how the opportunities opened by specific policies or resource distribution create gate keepers or gate openers; how it creates power stakes at the local level and rivalry for access to resources and constituencies; not the other way round: how the nature of party politics (its local pettiness, power tactics) links to (or impedes) the emergence of party policies, ideologies, or collective action. 